\title{
Management Governance Analysis in the Arab World: MANOVA Approach
}

\author{
Mahmoud MOURAD \\ Professor of econometric, Lebanese University \\ Faculty of Economics and Management (Branch 5) - Lebanon \\ Economics and Management Department \\ Address: Dr. Mahmoud MOURAD \\ PO box 128 \\ Nabatieh, Lebanon \\ Email: mourad.ul@gmail.com; mmrad@ul.edu.lb
}

Received: Sep. 7, 2018 Accepted: Sep. 26, 2018 Online published: Oct. 12, 2018

doi:10.5296/jpag.v8i4.13766 URL: https://doi.org/10.5296/jpag.v8i4.13766

\begin{abstract}
This paper studies 17 Arab States ${ }^{1}$, human development index (HDI), and 11 time series which represent the basic indicators of governance. These variables are freedom of trade, freedom of property, freedom of economy, freedom of finance, freedom of corruption, freedom of fiscal, freedom of money, freedom of enterprise, freedom of investment, freedom of work, and freedom of government spending. A multivariate variance analysis (MANOVA) was used to test whether a differential effect exists between the Arab countries, by first focusing on the types of regimes (monarchical or republican), and second on the group of Arab countries belonging to the GCC and the rest of Arab states. Our statistical results indicate a differential effect by the type of political system on the following governance variables: corruption, freedom of trade, freedom of economy and freedom of property.
\end{abstract}

1 The Arab states concerned with this study are: Algeria, Bahrain, Djibouti, Egypt, Jordan, Kuwait, Lebanon, Libya, Mauritania, Morocco, Oman, Qatar, Saudi Arabia, Syria, Tunisia, United Arab Emirates and Yemen. The other states as Iraq, Sudan, Somalia, and Palestinian Authority were not included in this analysis since the relative statistics for this study are absent or unreliable. 
Statistically speaking, in republican regimes, low values associated with the degree of freedom of corruption show that corruption is high and that it severely limits the freedom of individuals. Similarly, freedom of trade and freedom of economy in these regimes have more legislative or regulatory limitations, and little economic freedom compared to monarchies. Finally, concerning the degree of freedom of property, there are more expropriations and a higher level of corruption in the process of buying and selling goods. The inspection of the MANOVA results clearly indicates that the GCC countries are distinguished from other Arab countries based on six governance variables and the HDI indicator. Indeed, in the Arab countries of the GCC, we identify weaker corruption levels, a freedom of trade with less legislative or regulatory limits, a greater economic freedom, a fiscal freedom close to 100 (this means that the burden of paying taxes is lower and consequently individuals and companies have little tax liability), a fluctuated controlled monetary freedom, the human development index (HDI) is significantly higher, and finally a freedom of property with less expropriations and a lower level of corruption in the sale or purchase of goods. The high values of the HDI indicator in the GCC countries are partly explained by the indicator of gross domestic product per capita (IGDP) which is very high in those countries.

Keywords: Arabic regimes, republic, monarchy, governance, GCC, MANOVA analysis

\section{Introduction}

The Arab world is going through a critical phase in its history. What would the future of citizenship be? Issues regarding minorities and religions are a source of anxiety for the middle class which is being marginalized by the different waves of extremism. Popular movements first began in Tunisia and then (the winds of change) blew toward other republican regimes: Egypt, Yemen, Libya, and Syria whose situation is the most dramatic in the history of the Arab world. The question that immediately arises is: Why did the protests begin in countries with a republican regime? The republic is like a living being, and it needs some time to reach sufficient maturity in the individual as well as the collective consciousness. Everyone desires promising transitions that can bring positive change to the political and economic stability of each Arab country. In the Arab countries, middle class intellectuals do not miss any opportunity without talking about the importance of social justice, the cornerstone on which the edifice of citizenship is based. National security is achieved whenever citizens get hold of their rights which is the basic foundation of justice. What are the obstacles faced by the Arab countries? Who is responsible for monitoring and enforcing orders and instructions in public affairs? The obvious question is: If organizations and governmental agencies strive to coordinate and cooperate with each other in order to establish a country of citizenship, overcoming bureaucratic restrictions, how come corruption is found in both public and private administrations? Does this corruption result from a used up system of governance? Are our current governing practices in the different social, economic, financial, cultural and educational sectors no longer fit for the contemporary reality of our society? Are we afraid of a positive change that covers all our activities throughout our territory? Isn't the accumulation of negligence part of corruption? Why are the Arab countries unable to truly become independent? What is standing in the way of true development? Let us recall, for example, not restriction, that in France, two foreign ministers 
were forced to resign for mismanagement of public funds. Can we imagine such a scenario in one of the Arab countries? Whenever those in power abuse the richness of their nations, disregarding the public, the enforcement of anti-corruption laws is critical; only including such laws in the constitutions is not enough. The corruption leads to reduce the investment and hence it implies a decline in economic growth (Mauro 1995). We mention that, in the Arab world, the corruption had reached \$ 1 trillion over the period 1950 to 2000 (Ghoneim \& Ezzat (2016)), and according to the "Arab Anti-Corruption Organization" nearly a third of all gross national product (GNP have been wasted due to corruption" ${ }^{2}$.

Observing the behavior of the ruling class in the Arab World, whether in republican systems or in the constitutional monarchies, we see poor administration and lack of planning. The decisions in various fields are not based on scientific grounds, but rather on improvisation and speculation. It is not surprising to say that there is a problematic situation in the institutional life; the absence of the rule of law, the poor government performance and hence the lack of effectiveness, all of which are reflected in all government departments. Hence, all manifestations of instability in the Arab societies are the result of the way governments plan, a way that lacks good governance in all areas (Harb 2017).

For the nongovernmental organization "Transparency International" (TI) ${ }^{3}$, the lack of transparency in the fight against corruption in the Arab world is due to the executive powers lacking political will, the security apparatus' weak control mechanisms, the marginalization of the role of civil society which is subject to the influence of leaders and decision makers. In this respect, we cannot deny the rather negative role of the media, which in most cases, distorts the truth from the public; also they greatly contribute to maintaining the status quo and the impact of favouritism imposed by the political "tradition". According to the (TI) organization, the corruption has worsened in most of the Arab countries since the revolutions of the "Arab Spring"4! Is the lack of true democracy in the Arab world primarily responsible for the corruption? Most Arab countries have had their independence for over 50 years. How come the successive political regimes have not yet been able to create a democratic Arab citizen? Do these regimes have the ability to democratize themselves or create the appropriate conditions for progressive democratization based on education? It is true that the Arab political regimes have succeeded a colonial period, and "supreme" rulers inherited, from the colonial period, the character of domination and they have not established a climate that encourages the creation of individual autonomous model citizens. The main concern of most of the leaders was the distribution of the benefits resulting from power and privilege. Most of what Arab leaders have done has stood in the face of modernization and the creation of patriotic democratic institutions that can reach to the entirety of the people, not only fractions of a certain area or religion. Democracy is not the work of magic, but it is the result of daily implementation and especially in education. If our societies are not trained enough for democracy then they will break down upon the first internal conflict. The objective of this paper is not political in nature, and it is not intended to distort the public opinion, but rather to

\footnotetext{
${ }^{2}$ http://arabanticorruption.org/articleCat/74

3 Transparency International is now an international non-governmental organization

${ }^{4}$ Transparency International's Global Corruption Barometer- report (July 2013).
} 
help policy makers in the decision-making process. The results obtained can contribute to signal the need for a positive reform by the governments concerned. For this purpose, we will use 12 variables, from which 11 are related to governance according to Transparency International and the last is the human development index (HDI). These variables are:

1- Corruption degree freedom

3- Entrepreneurial degree freedom

5- Financial degree freedom

7- Government spending degree freedom

9- Monetary degree freedom

11- Work degree freedom
2- Trade degree freedom

4- Economic degree freedom

6- Fiscal degree freedom

8- Investment degree freedom

10- Property degree freedom

12- Human development index (HDI)

Each of the 12 variables is considered as a dependent variable, and we have retained temporal data for the following years: 2000, 2003, 2006, 2009 and 2012, except for the variables HDI and freedom in work with data corresponding to $(2005,2009,2010,2011,2012)$ and $(2008$, $2009,2010,2011,2012)$ respectively. So each dependent variable is a vector of the space $R^{D}(D=5)$. The methodology used is that of the multivariate analysis of variance (MANOVA). Indeed, it is a statistical test that aims at determining whether qualitative factors have significant effects on several quantitative dependent variables taken collectively. In our case, we have only one factor that is, on the first hand, the type of political regime of an Arab country: republic (level 1) and monarchy (level 0), and on the second hand, the GCC countries (level 1) and the other Arab countries (level 0). So the proposed factor has two levels $(J=2)$. The estimation of parameters will be made by the method of maximum likelihood treating each observation as a realization of a multivariate Gaussian distribution. For a given variable, if the statistical test reveals a differential effect between the two levels of our factor, then a significant difference in governance will be announced by focusing on the difference in the performance of the type of regime, and consequently, we can recommend a kind of revision of the control systems to improve the performance of governance management signalling that according to the World Bank (1992), the good governance is synonymous with sound development management. In this regard, a big question is imposed: Is it a problem of regime type or governance management in the Arab world? Isn't the quality of management (good or bad) a factor determining the quality of the economic and social life of a country? Good governance management is certainly based on the consciousness of ethics and transparency. Up to this day, the Arab world knows 7 types of political regimes: Presidential with prime minister (2 States), presidential without prime minister (1 State), semi-presidential (7 States), parliamentary (2 States), and transitional (1 State), and constitutional monarchy where the monarch has effective power (5 States) and absolute constitutional monarchy ( 3 States). Yet this wide diversity in the Arab political regimes can divide the Arab countries into two main groups: "republican" regimes and 
monarchical regimes.

Briefly, our study aims, on the one hand, to compare the 11 governance indicators and the HDI indicator between the 17 Arab countries having available statistics, and on the other hand, to see if there is a difference statistically significant between the two categories of regimes monarchy and republic.

The article is divided into six sections. After this introduction presented in section one, the second is an overview of the selected governance indicators. The third section briefly presents the literature that closely discusses the issue of governance and the fourth section presents the methodology of multivariate analysis of variance (MANOVA). The fifth section is about the results of the statistical analysis and the sixth section is reserved for conclusion.

\section{Definition and Aggregate Indicators of Governance}

In this section, we will allocate the essential facts that inform about the governance and its indicators focusing our attention on corruption, which is the most threatening disease of the status quo of the Arab countries.

\subsection{Governance}

Over the past two decades, there has been a dramatic increase in the use of hundreds of specific indicators to measure the quality of governance particularly in developing countries and emerging economies. What effective management must the political authorities take to revive the economy of a country? How to improve the quality of life of human beings, citizens of these countries? How to manage the development of factors, on all levels, related to health, education and economic growth? While searching the term "governance" we found, for example, Yenikoye (2004) that relates governance to the analysis of management methods and government of developing countries. Is it about the effective functionality of government? According to the World Bank (1992), the concept of good governance has been adopted by various international and regional organizations. The governance is defined as "the way power is exercised in the management of economic and social resources of a country for the purpose of development." For UNDP (1997), and Djaow (2009), the governance is "the exercise of political, economic and administrative authority for managing the affairs of a country." For some countries such as the Republic of Congo, the governance has four dimensions: the political, administrative, economic and financial, and corporate governance. In all these definitions, we distinguish between two categories of the population: the class that controls the application of management governance programs and the majority of the population formed by all citizens. The big question that arises is: under what criteria, political, economic and administrative, have officials been selected for the implementation of the governance in question? Is there a criterion based on the principle of citizenship where the rule of law is the main axis around which the whole society pivots? What is the situation of the transparency and integrity of officials in public administration? Under what level do fraud and corruption reside in public servants? Is there a link between good governance, peace and social stability? It seems that these issues are interdependent and inseparable. But we cannot acquire peace and social stability without adopting a good governance management policy. 
Internal social conflicts have very adverse effects on any hope of a sustainable economic recovery. For this, countries based on the rule of law give great attention to these three factors which are the primary prerequisites for the fight against poverty and a sustainable human development. From all the definitions of governance, Miossec (2008) adopts the definition that focuses on "the capacity and co-responsibility of projects, the possibility of establishing a collective framework of joint action, strategic thinking between the main actors in the political decision making process. For the measuring governance and corruption, see Apaza (2009). Let us now present the various governance indicators discussed in our paper.

\subsection{Governance Indicators}

The most commonly used indicators are those so-called "composite or aggregate" which are based on perceptions. Each indicator is reduced to an annual figure that results from information provided by many sources and it reflects the perceptions of experts, businesses and households surveys. Before presenting the theoretical framework and practical implementation of various MANOVA models to see if the type of political regimes, republican or monarchical, or GCC group and other Arab countries, has a differential effect on each of the indicators; we will make a brief presentation of the meaning of governance for each of the 12 indicators. We note that these indicators suffer a weakness in their statistics as a tool for comparing the quality of governance across countries and / or time. In table 1, we explained the meaning of each indicator according to its value close to 100 or close to 0 :

Table 1. Governance indicators

\begin{tabular}{|c|c|c|}
\hline Variable & Institution & Informations \\
\hline Trade freedom & $\begin{array}{l}\text { Fondation } \\
\text { Heritage } \\
\text { Wall Street } \\
\text { Journal }\end{array}$ & $\begin{array}{l}\text { A degree close to } 100 \text { means that the trade is easy and without } \\
\text { many legislative or regulatory limits. Conversely a degree } \\
\text { close to } 0 \text { means that the commercial freedom is reduced or } \\
\text { non-existent. }\end{array}$ \\
\hline $\begin{array}{l}\text { Corruption } \\
\text { freedom }\end{array}$ & $\begin{array}{l}\text { Transparency } \\
\text { International }\end{array}$ & $\begin{array}{l}\text { A degree close to } 100 \text { means that the corruption is low. } \\
\text { Conversely a degree close to } 0 \text { means that the corruption is } \\
\text { great and limits the freedom of individuals strongly. }\end{array}$ \\
\hline $\begin{array}{l}\text { Government } \\
\text { spending } \\
\text { freedom }\end{array}$ & $\begin{array}{l}\text { Fondation } \\
\text { Heritage } \\
\text { Wall } \\
\text { Journal }\end{array}$ & $\begin{array}{l}\text { A degree close to } 100 \text { means that the government spending as a } \\
\text { percentage of GDP is very small. Conversely, a degree closer to } \\
0 \text { means that the government spends heavily on its many } \\
\text { spending programs. }\end{array}$ \\
\hline $\begin{array}{l}\text { Economic } \\
\text { freedom }\end{array}$ & $\begin{array}{l}\text { Fondation } \\
\text { Heritage } \\
\text { Wall } \\
\text { Journal }\end{array}$ & $\begin{array}{l}\text { A degree close to } 100 \text { means a lot of economic freedoms for } \\
\text { the country. Conversely a degree close to } 0 \text { means that there are } \\
\text { few economic freedoms. }\end{array}$ \\
\hline $\begin{array}{c}\text { Entrepreneurial } \\
\text { freedom }\end{array}$ & $\begin{array}{l}\text { Fondation } \\
\text { Heritage } \\
\text { Wall } \\
\text { Journal }\end{array}$ & $\begin{array}{l}\text { A degree close to } 100 \text { means that the freedom for companies is } \\
\text { great: weak legislative or regulatory constraints to start a } \\
\text { business obtain licenses or close the business. }\end{array}$ \\
\hline Financial freedom & Fondation & A degree close to 100 means that the government intervenes \\
\hline
\end{tabular}




\begin{tabular}{|c|c|c|c|}
\hline & $\begin{array}{l}\text { Heritage } \\
\text { Wall } \\
\text { Journal }\end{array}$ & Street & $\begin{array}{l}\text { little in the financial field: the independence of the banks is } \\
\text { thus extended. Governments limit themselves to ensuring } \\
\text { compliance with contracts or preventing fraud. }\end{array}$ \\
\hline Fiscal freedom & $\begin{array}{l}\text { Fondation } \\
\text { Heritage } \\
\text { Wall } \\
\text { Journal }\end{array}$ & Street & $\begin{array}{l}\text { A degree close to } 100 \text { means that the tax burden is low: } \\
\text { individuals and businesses have low taxes to pay. In Bahrain, } \\
\text { Kuwait, the United Arab Emirates and Qatar tax, the freedom is } \\
\text { very high since over } 95 \text {. }\end{array}$ \\
\hline $\begin{array}{c}\text { Investment } \\
\text { freedom }\end{array}$ & $\begin{array}{l}\text { Fondation } \\
\text { Heritage } \\
\text { Wall } \\
\text { Journal }\end{array}$ & Street & $\begin{array}{l}\text { A degree close to } 100 \text { means that the investments can be made } \\
\text { with few limits. Some countries have great freedom in this } \\
\text { respect: Luxembourg, Denmark and the United Kingdom. } \\
\text { Conversely, North Korea, but also Zimbabwe, Iran, and Cuba } \\
\text { have virtually non-existent freedom. }\end{array}$ \\
\hline Monetary freedom & $\begin{array}{l}\text { Fondation } \\
\text { Heritage } \\
\text { Wall } \\
\text { Journal }\end{array}$ & Street & $\begin{array}{l}\text { A degree close to } 100 \text { means that the currency is not } \\
\text { constrained by government interference. Conversely, a degree } \\
\text { close to } 0 \text { means that policymakers fully control the currency } \\
\text { according to their objectives. }\end{array}$ \\
\hline Property freedom & $\begin{array}{l}\text { Fondation } \\
\text { Heritage } \\
\text { Wall } \\
\text { Journal }\end{array}$ & 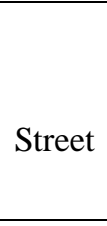 & $\begin{array}{l}\text { A degree close to } 100 \text { means that the private property is } \\
\text { protected by laws and the justice system. Expropriations would } \\
\text { be rare and the level of corruption for the sale or purchase of } \\
\text { property is low or even nil. }\end{array}$ \\
\hline Work freedom & $\begin{array}{l}\text { Fondation } \\
\text { Heritage } \\
\text { Wall } \\
\text { Journal }\end{array}$ & Street & $\begin{array}{l}\text { A degree close to } 100 \text { means that the work is poorly regulated } \\
\text { by laws and regulations. Thus, there are few limitations on the } \\
\text { minimum wage, hours of work, hiring and firing of employees. } \\
\text { Freedom of work is thus associated with the freedom of } \\
\text { employers or the freedom of employees to change employers. }\end{array}$ \\
\hline
\end{tabular}

\section{Source : Sherbrooke University - Quebec - Canada}

Fatafta (2018) considers that corruption remains endemic in the Arab states, Hattar (2017) rules out the hope to fight corruption and end impunity. Andrei et al. (2007) have considered that the corruption level depends on a series of factors such as the political system pressure, the administration transparency, the quality of the civil servants' job-related relationships.

Regarding the relationship between corruption and property, we find it useful to cite an interesting result given by Mourad (2013) ${ }^{5}$ indicating that if the corruption levels increase, then the degree of freedom of property also increases. To illustrate this result for Arab countries, we used data of the year (2010) taking the degree of freedom of property (dependent variable $\mathrm{Y}$ ) and the degree of freedom of corruption (explanatory variable $\mathrm{X}$ ). The figure (1) reveals the presence of a positive linear relationship between the two variables. The

\footnotetext{
${ }^{5}$ The result of the regression is based on a seminar done by Mahmoud Mourad in 2013 at the Lebanese University, Faculty of Economics and Management (branch 5). Several tests were used to test the homoscedasticity of errors: test for Spearman rank coefficient correlation, Goldfield-Quandt test, Glejser test, Breusch-Pagan test, Harvey test and White test. The results of these tests promote the acceptance of the null hypothesis of homoscedasticity at $5 \%$.
} 
estimated regression model is ( $\mathrm{t}$-statistics between parentheses):

$$
\begin{gathered}
\widehat{\mathrm{Y}}_{\mathrm{i}}=\underset{(0.63)}{3.3208+0.9462 \mathrm{X}} \\
(7.36) \\
\mathrm{R}^{2}=78.34 \%, \overline{\mathrm{R}}^{2}=76.90 \%
\end{gathered}
$$

Inspecting the results of the simple regression, it is clear that the linear relationship is strong between the degree of freedom of corruption and degree of freedom of property. The slope is positive and significantly different from zero. This means that corruption has an impact on property. If $\mathrm{X}$ increases by one unit, then $\mathrm{Y}$ increases by 0.95 units.

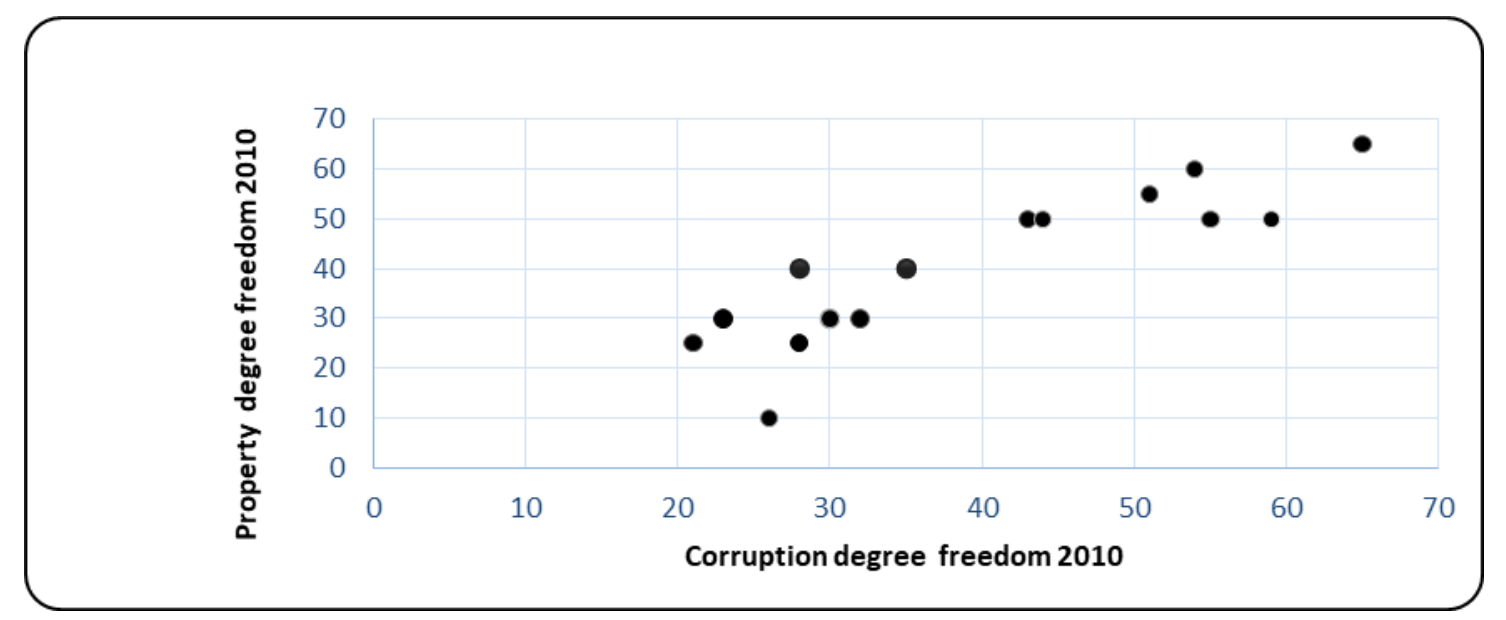

Figure 1. Examining the linear relationship between property degree freedom and corruption degree freedom

Finally, about the Human Development Index (HDI), before 1990, the World Bank ranked countries (188 countries in 2012), according to GDP per capita. However, GDP does not take into account the following key points: the unequal distribution of income among the citizens of a country, differences in terms of purchasing power of currencies, the situations of the educational system and the health sector. To do this, another more informative indicator that gives greater weight to the quality of human life had to be used. Several indicators have been proposed, among which was the Human Development Indicator (HDI). Other indicators, for example, are the Women's Participation in Decision Making (WPDM) and Human Poverty Indicator (HPI). The new HDI indicator has three dimensions: longevity (long and healthy life), education (degree of literacy, different levels of education) and access to resources needed for a decent standard of living. The above mentioned quantitative and measurable variables can also be defined as Longevity: It is measured by life expectancy at birth. It varies between 25 and 85 years.

The level of education: it is measured by a combination of adult literacy and enrollment rates. Each of these two rate ranges between 0 and $100 \%$.

Access to resources: This variable is measured by income per capita (PPP), which varies between $\$ 100$ and $\$ 40,000$. The formula for calculating the components of HDI is: 


\section{Real value - Minimum value \\ Maximum value - Minimum value}

Formula for calculating HDI:

$$
\mathrm{HDI}=\frac{\mathrm{ILE}+\mathrm{IEL}+\mathrm{IGDP}}{3}
$$

ILE is the indicator of life expectancy, IEL means the indicator of educational level and IGDP represents the indicator of gross domestic product per capita. The educational indicator is composed of a literacy indicator (weight 2/3) and a schooling indicator (weight 1/3). These three variables have the same weight because they are equal in terms of importance. The HDI indicator therefore measures the happiness and the desirable standard of living.

Since the HDI is based on three quantitative variables, the ranking of countries in our world is made according to the values assigned to each of these variables. We obtain four categories of countries (United Nations Development Programme (UNDP) (2012):

a- Very high HDI (HDI $\geq 0.800)$

b- High HDI $(0.710 \leq \mathrm{HDI}<0.800)$

c- Medium HDI $(0.535 \leq$ HDI $<0.710)$

\section{d- Low HDI (HDI <0.535)}

We conclude this section by noting that HDI is not an indicator of governance, because it ignores the freedom of citizens, their rights and other factors related to civil peace. Caution is needed when dealing with HDI. It would be better to make an econometric analysis of the three variables mentioned above to see how these variables, taken over a number of years, are interdependent and hence study the cross of information between them; an analysis that combines the short term and the long term. The UNDP report (2012) on the Human Development Index (HDI) ranks countries in the world in 4 levels: very high, high, medium and low. An inspection of this report ranks the Arab countries in different levels: Qatar and UAE are classified as "very high" ranks 36 and 41 respectively. In fact, the HDI provides a composite measure of three basic dimensions of human development: health, education and income.

\section{Literature Review}

In the literature, there are two types of governance indicators. The first type is related to economic growth and uses an econometric approach focused on the development of economic activity including the investment of the economy relative to the GDP ratio (OECD 2005). This indicator reflects the tendency of the State and individuals to invest in the country. Therefore, this indicator is also a criterion of overall participation in the financing of economic activities in a country. In this regard, we mention the paper by Ahishakiye (2009) who uses an approach in terms of causality between variables associated with economic growth and those related to economic governance. Economists admit a positive role of foreign direct investment (FDI) in the development and poverty reduction. Bonny (2005) uses 
econometric models to measure the negative effects of poor governance in Haiti on FDI inflows by making a survey of the empirical links between FDI and a number of suitably chosen variables. The second type takes into account the focus on the economic environment including inflation indicators, tax burden, tax revenue (\% of GDP), total government expenditure ( $\%$ of GDP), health expenditure ( $\%$ of total expenditure), expenditure on education ( $\%$ of total expenditure). These indicators reflect the will of public authorities to clean up the business environment and, thus, create an environment conducive to sustainable growth and ensuring access to resources needed for a decent standard of living. It is known that high inflation rates make the individual financial planning difficult and increase uncertainty in business (Ndinga, 2002). Similarly, a high tax burden discourages investment and hinders economic growth. According to a report published by the World Bank (2003), there has been a delay in economic growth in the regions of the Middle East and North Africa (MENA), and the origin of the delay amounts to the lack of governance. From Casablanca-Morocco to Beirut- Lebanon, public governance relations occur in almost all situations in which individuals and groups interact with government. Are there fluid and productive interactions? In principle, public governance is the exercise of authority on behalf of the population, so good governance must respect the integrity, rights and needs of everyone within a State. The quantitative study of the Quality Index of Global Governance, based on 22 indicators, shows that in the MENA region, the quality of governance increases with income. In comparison with other regions in the world, MENA displays an obvious delay in governance. The 14 Arab countries in the MENA region that have been concerned with this study are Algeria, Egypt, Bahrain, Jordan, Kuwait, Lebanon, Morocco, Oman, Qatar, Yemen, Saudi Arabia, Syria, Tunisia and the United Arab Emirates. Countries, in the MENA region as well as the rest of the world, with high-income, have average governance that is twice that of low-income countries. The study by the World Bank concludes that MENA appears last in the Quality Index of Global Governance.

Despite the importance of the econometric approach in the analysis of governance in the Arab world based on the economic factors mentioned above, we will limit ourselves, for the moment, to test whether a significant statistical difference exists between the Arab countries adopting republican regimes and those being monarchies, then follow the same process by dividing the Arab countries to those belonging to the GCC and those that do not. Unfortunately, we do not have enough empirical studies that cover all Arab countries, for example, in terms of agriculture, investment and foreign trade between the Arab world and the rest of the world. We report our need for comparative studies of governance between the Arab countries and developed countries that reflect the economic variables that are related to the quality of governance. Indeed, many studies have been done on the economic and financial situation of the Arab States, especially the GCC countries. We mention, for example, a recent article published by Nazer (2016) suggesting that, in Saudi Arabia, the fiscal policy plays a critical role in the economic system, Mourad and Henniche (2014) declared the need for a deep governance in the Arab world if not the different countries will witness a serious social disintegration. Bou-Hamad et al. (2013) have used an advanced econometric approaches to measure the ratio of external trade of the GCC countries with the United States, Halleröd et al. (2013) have highlighted the impact of bad governance on people's living 
conditions, Merza and Cader (2009) have estimated a unit value of the GCC common currency, Wigg, et al. (2007) have focused on the role of willing and capable governments to foster economic growth and poverty reduction.

In fact, the study of governance in the Arab world has been very limited. In this respect, we mention the work done by Ben Néfissa (2000) on measures of good governance in the Arab world by drawing attention to the quality of a decentralized administration, an effective and transparent public function, a reliable legal system and an effective fight against corruption. Building of a civil society is done in both directions: from the bottom up and top down. This objective will not be achieved without exploiting resources that lead to the development of civil liberties and leads to public debates with the freedom of the press, and finally ensure all the conditions that underpin the building of respect for human rights and establish the "rule of law". Some authors believe in the presence of a strong link between good governance and democracy in a civil society. Castel (2006) concludes his work on the fact that "people should write their own history; imposing from the outside and from the top, a "good governance" may give opposite results to those expected, especially as the method is inherently undemocratic." According to Zimeray (2010), (Ambassador of France for human rights), good governance has to transform the ideal, when it comes to human rights, into the standard applied. It is known today that the advances in information and communication systems have made the world a global village, and as a result a given political regime cannot get away from changes that may occur in the world. We conclude this section by noting that our goal is not to find an indicator of the quality of governance, but rather to use temporal data of governance indicators to conduct a comparative study among the Arab countries.

\section{Analysis Method and Formulation of Operational Assumptions}

In this section, we will briefly present the approach to multivariate variance analysis of variance (MANOVA). We note that this approach is heavily used in medical as well as social discrimination studies and in all fields whose data of the variable of interest vary according to an appropriate classification or a change in level of a nominal qualitative variable. In our case, we have one factor $\mathrm{F}$ at two levels ( 0 and 1 ), so $\mathrm{J}=2$, by first focusing on the types of regimes (monarchical or republican), and second on the group of Arab countries belonging to the GCC and those that do not. For each country, Algeria, for example, the regime is republican $(\mathrm{j}=1)$, and we have a dependent variable, for example corruption during $\mathrm{D}$ periods of time $(\mathrm{D}=5): \mathrm{Y}_{11}=(50,50,27,30,29)$ is a row vector in $\mathrm{R}^{\mathrm{D}}$. The MANOVA model is written as:

$$
\mathrm{Y}_{\mathrm{ij}}=\beta_{\mathrm{j}}+\varepsilon_{\mathrm{ij}}
$$

Where $Y_{i j}=\left(Y_{i j}^{1}, Y_{i j}^{2}, \ldots, Y_{i j}^{D}\right)$ is a row vector in $R^{D}$. The vector $\beta_{j}=\left(\beta_{j}^{1}, \beta_{j}^{2}, \ldots, \beta_{j}^{D}\right)$ is comprised of $\mathrm{D}$ parameters to be estimated, and it models the value of the response $\mathrm{Y}$ in level $\mathrm{j}$ of the factor $F$. The vector $\varepsilon_{\mathrm{ij}}=\left(\varepsilon_{\mathrm{ij}}^{1}, \varepsilon_{\mathrm{ij}}^{2}, \ldots, \varepsilon_{\mathrm{ij}}^{\mathrm{D}}\right)$ is a row vector of random errors in $\mathrm{R}^{\mathrm{D}}$. We suppose that $\varepsilon_{\mathrm{ij}}$ are independent identically distributed (i.i.d) following a normal law $\mathbf{N}(\mathbf{0}, \mathbf{\Sigma})$ where $\Sigma$ 


\section{Ml Macrothink}

is a symmetric and strictly positive-definite matrix, it will be estimated using available data. Since the model considered is assumed homoscedastic, the matrix $\Sigma$ does not depend on $\mathrm{j}$. The random vectors $Y_{i j}$ are independent and normally distributed $N\left(\beta_{j}^{r}, \Sigma\right)$. The number of parameters is $\quad J \times D($ here $2 \times 5=10)$ with $\frac{D(D+1)}{2}$ variance parameters. We, therefore, have $\mathrm{n} \times \mathrm{D}=17 \times 5=85$ observations; we must ensure that the size $\mathrm{n}$ of the sample verifies that $\mathrm{n}>\mathrm{J}+\frac{\mathrm{D}+1}{2}$ (condition is met). We note that the Arab countries involved in this study are 17 countries (Iraq, Palestinian Authority, Sudan and Somalia are excluded because of the absence of reliable statistics). There are 9 republican regimes: Algeria, Egypt, Djibouti, Lebanon, Libya, Mauritania, Syria, Tunisia and Yemen. And 8 monarchical regimes: Saudi Arabia, Bahrain, UAE, Jordan, Kuwait, Morocco, Oman and Qatar. The MANOVA model can be written in matrix form: $\mathrm{Y}=\mathrm{X} \beta+\varepsilon$ where $\mathrm{Y}$ and $\varepsilon$ are random matrices of the same size $\mathrm{n} \times \mathrm{D}=17 \times 5$. $\mathrm{X}$ is a matrix of size $\mathrm{n} \times \mathrm{J}$ and $\beta$ is a matrix of size $\mathrm{J} \times \mathrm{D}$. $\mathrm{Y}$ and $\varepsilon$ are Gaussian, of same variance, and satisfy:

$\mathrm{E}(\varepsilon)=0$ (a null matrix of size $\mathrm{n} \times \mathrm{D}) \mathrm{E}(\mathrm{Y})=\mathrm{X} \beta$ and $\mathrm{V}(\mathrm{Y})=\mathrm{V}(\varepsilon)=\mathrm{I}_{\mathrm{n}} \otimes \Sigma$ where $\otimes$ represents the Kronecker product:

$V(Y)=\left(\begin{array}{cccccc}\Sigma & 0 & 0 & 0 & \ldots & 0 \\ 0 & \Sigma & 0 & 0 & \ldots & 0 \\ & \ldots & \ldots & \ldots & \ldots . & 0 \\ 0 & 0 & 0 & 0 & \ldots & \Sigma\end{array}\right)$ Where $\Sigma$ is a symmetric matrix of size $\mathrm{D} \times \mathrm{D}$ and 0 is a bull matrix of the same size. So $V(Y)$ is a square matrix of order $\mathrm{nD}$. We will use a centered parameterization of breaking down each row vector $\beta_{j}=\left(\beta_{j}^{1}, \beta_{j}^{2}, \beta_{j}^{3}, \beta_{j}^{4}, \beta_{j}^{5}\right)$ into the form:

$$
\beta_{\mathrm{j}}=\mu+\beta_{\mathrm{j}}-\mu=\mu+\alpha_{\mathrm{j}}
$$

With $\mu=\frac{\sum_{i=1}^{I} \beta_{i j}}{I}$. The parameter $\mu$ is the general average effect and the parameter $\alpha_{j}$ is the main or differential effect of level $\mathrm{j}$ of $\mathrm{F}$. These two parameters are vectors in $\mathrm{R}^{\mathrm{D}}$ and it is noted that $\sum_{\mathrm{j}=\mathbb{1}}^{\mathrm{I}} \alpha_{\mathrm{j}}=0$. Parameter estimation is done by the maximum likelihood method. The null hypothesis is written in one of the following forms:

$$
\mathrm{H}_{0} \text { : F has no effect on } \mathrm{Y} \Leftrightarrow \mathrm{H}_{0}: \beta_{1}=\cdots=\beta_{\mathrm{I}} \quad \Leftrightarrow \mathrm{H}_{0}: \quad \alpha_{1}=\cdots=\alpha_{\mathrm{I}}=0
$$

The implementation of a test for testing $\mathrm{H}_{0}$ against its alternative $\mathrm{H}_{1}$, with a fixed level $\alpha$ requires generalizing the Fisher test. It is required to estimate tow matrices, $\mathrm{H}$ and $\mathrm{E}$, of size $\mathrm{D} \times \mathrm{D}$ with:

$$
\begin{aligned}
& \mathrm{H}=\mathrm{n}_{1} \mathrm{~V}+\mathrm{n}_{0} \mathrm{~W} \\
& V=\left(\begin{array}{c}
\bar{y}_{.1}^{1}-\bar{y} \\
\bar{y}_{.1}^{2}-\bar{y} \\
\bar{y}_{0}^{3}-\bar{y} \\
\bar{y}_{.1}^{4}-\bar{y} \\
\bar{y}_{.1}^{5}-\bar{y}
\end{array}\right)\left(\begin{array}{c}
\bar{y}_{.1}^{1}-\bar{y} \\
\bar{y}_{.1}^{2}-\bar{y} \\
\bar{y}_{.1}^{3}-\bar{y} \\
\bar{y}_{.1}^{4}-\bar{y} \\
\bar{y}_{.1}^{5}-\bar{y}
\end{array}\right)^{\prime} \quad W=\left(\begin{array}{c}
\bar{y}_{0}^{1}-\bar{y} \\
\bar{y}_{0}^{2}-\bar{y} \\
\bar{y}_{0}^{3}-\bar{y} \\
\bar{y}_{.0}^{4}-\bar{y} \\
\bar{y}_{0}^{5}-\bar{y}
\end{array}\right)\left(\begin{array}{c}
\bar{y}_{.0}^{1}-\bar{y} \\
\bar{y}_{0}^{2}-\bar{y} \\
\bar{y}_{0}^{3}-\bar{y} \\
\bar{y}_{.0}^{4}-\bar{y} \\
\bar{y}_{0}^{5}-\bar{y}
\end{array}\right)^{\prime}
\end{aligned}
$$


$\mathrm{E}=\sum_{\mathrm{j}=\mathbb{1}}^{\mathrm{I}} \sum_{\mathrm{i}=\mathbb{1}}^{\mathrm{n}_{\mathrm{i}}}\left(\mathrm{y}_{\mathrm{ij}}-\overline{\mathrm{y}}_{\mathrm{j}}\right)^{\prime}\left(\mathrm{y}_{\mathrm{ij}}-\overline{\mathrm{y}}_{\mathrm{j}}\right)=\hat{\varepsilon}^{r} \hat{\varepsilon} \quad$ The degrees of freedom $(\mathrm{df})$ associated with the matrices $\mathrm{H}$ and $\mathrm{E}$ are respectively $\left(v_{H}=\mathrm{J}-1\right)$ and $\left(v_{E}=\mathrm{n}-\mathrm{J}\right)$. In single-factor MANOVA, testing the significance of a factor is based on one of the following matrix products: $\mathrm{HE}^{-1}$ or $\mathrm{H}(\mathrm{H}+\mathrm{E})^{-1}$ Note that $\widehat{\Sigma}=\frac{1}{n-I} \hat{\varepsilon}^{r} \hat{\varepsilon}=\frac{E}{n-I}=\frac{E}{v_{E}}$. To test whether a differential effect exists between the levels of the factor in question, the Wilks test (Seber 2004) ${ }^{6}$ is used. The test's statistics are given by:

$$
\Lambda=\frac{\operatorname{det}(E)}{\operatorname{det}(H+E)}=\prod_{k=1}^{s} \frac{1}{1+\lambda_{k}}
$$

Where $\lambda_{k}$ are the eigenvalues of the matrix $\mathrm{HE}^{-1}$ and where $\mathrm{s}=\inf (\mathrm{D}, \mathrm{J}-1)$ is the number of non-zero eigenvalues of the same matrix. When this statistic is significant, it indicates that all the dependent variables allow distinguishing the two groups. So in the multivariate case, the test must be done once and any use of the univariate case will increase the risk of incorrectly rejecting the null hypothesis. Moreover the components of the dependent random vector are not independent, especially in the case of auto-correlated time series. Testing them individually, we completely omit any eventual interactions. Our statistical calculations were made using SPSS software (version 19).

\section{Implementation of the MANOVA Approach}

In the following, we will use the MANOVA approach to measure whether there is a differential effect between the different groupings of Arab countries, as specified previously. The MANOVA will obtain a multivariate $F$ reflecting the overall difference between the two groups taking into account all the information carried by five years (dependent variables). If the Wilks statistic exceeds the critical value $\mathrm{F}_{0.95}(5,11)=3.2$, then we reject the null hypothesis (the type of regime of group does not affect the variable in question).

Table 2. MANOVA Analysis : type of political regimes

\begin{tabular}{l|c|l|l}
\hline \multicolumn{1}{c|}{ Variable } & $\begin{array}{c}\text { Wilks } \\
\text { Statistics }\end{array}$ & Decision & \multicolumn{1}{c}{ Conclusion } \\
\hline Corruption freedom & 4.24 & Reject $H_{0}$ & The type of regime has an impact on corruption \\
\hline Trade freedom & 9.21 & Reject $H_{0}$ & $\begin{array}{l}\text { The type of regime has an impact on freedom of } \\
\text { trade (except for Lebanon, Libya and Yemen } \\
\text { during 2009 and 2012) }\end{array}$ \\
\hline Economic freedom & 6.66 & Reject $H_{0}$ & $\begin{array}{l}\text { The type of regime has an impact on economical } \\
\text { freedom }\end{array}$ \\
\hline
\end{tabular}

${ }^{6}$ We note that several tests can be used to test the null hypothesis. We cite, for example, the test of the Hotelling-Lawley trace, the test of the Pillai trace and the test of the larger root of Roy. In the case of a factor with two levels, the statistics associated with these three tests are identical. 


\begin{tabular}{|c|c|c|c|}
\hline $\begin{array}{l}\text { Entrepreneurial } \\
\text { freedom }\end{array}$ & 2.38 & Accept $H_{0}$ & $\begin{array}{l}\text { The type of regime has no impact on } \\
\text { entrepreneurialfreedom }\end{array}$ \\
\hline Financial Freedom & 2.90 & Accept $H_{0}$ & $\begin{array}{l}\text { The type of regime has no impact on financial } \\
\text { freedom }\end{array}$ \\
\hline Fiscal freedom & 2.65 & Accept $H_{0}$ & $\begin{array}{l}\text { The type of regime has no impact on fiscal } \\
\text { freedom }\end{array}$ \\
\hline $\begin{array}{l}\text { Government spending } \\
\text { freedom }\end{array}$ & 1.03 & Accept $H_{0}$ & $\begin{array}{l}\text { The type of regime has no impact on government } \\
\text { spending }\end{array}$ \\
\hline Investment freedom & 1.11 & Accept $H_{0}$ & $\begin{array}{l}\text { The type of regime has no impact on freedom } \\
\text { for investment }\end{array}$ \\
\hline Monetary freedom & 2.27 & Accept $H_{0}$ & $\begin{array}{l}\text { The type of regime has no impact on monetary } \\
\text { freedom }\end{array}$ \\
\hline $\begin{array}{l}\text { Human development } \\
\text { index (HDI) }\end{array}$ & 2.16 & Accept $H_{0}$ & The type of regime has no impact on HDI \\
\hline Property freedom & 5.58 & Reject $H_{0}$ & $\begin{array}{l}\text { The type of regime has an impact on freedom of } \\
\text { property }\end{array}$ \\
\hline Work Freedom & 0.83 & Accept $H_{0}$ & $\begin{array}{l}\text { The type of regime has no impact on freedom } \\
\text { of work }\end{array}$ \\
\hline
\end{tabular}

Inspection of Table (2) reveals very important information: the type of political regime has an impact on the governance variables of freedom of corruption, freedom of trade, economic freedom and freedom of property. For these 4 variables, a value close to zero indicates that the corresponding countries have lots of legislative or regulatory limits. The MANOVA results announce a differential effect between the republican regimes and monarchical ones. Statistically speaking, in republican regimes, low values associated with the degree of freedom of corruption, mean that corruption is relatively high compared to monarchies, and it severely restricts the freedom of individuals, similarly for the freedom of trade and economic freedom. Finally, for the degree of freedom of property, there are more expropriations and a higher level of corruption in the sale or purchase of goods.

Table 3. MANOVA Analysis - GCC group and group of other Arab countries

\begin{tabular}{l|c|l|l}
\hline \multicolumn{1}{c|}{ Variable } & $\begin{array}{c}\text { Wilks } \\
\text { Statistics }\end{array}$ & Decision & \multicolumn{1}{c}{ Conclusion } \\
\hline Corruption & 8.97 & Reject $H_{0}$ & The type of group has an impact on corruption \\
\hline Freedom of trade & 5.40 & Reject $H_{0}$ & $\begin{array}{l}\text { The type of group has an impact on freedom of } \\
\text { trade }\end{array}$ \\
\hline Economic freedom & 3.44 & Reject $H_{0}$ & $\begin{array}{l}\text { The type of group has an impact on economic } \\
\text { freedom }\end{array}$ \\
\hline $\begin{array}{l}\text { Entrepreneurial } \\
\text { freedom }\end{array}$ & 1.38 & Accept $H_{0}$ & $\begin{array}{l}\text { The type of group has no impact on entrepreneurial } \\
\text { freedom }\end{array}$ \\
\hline Financial Freedom & 0.99 & Accept $H_{0}$ & The type of group has no impact on financial freedom \\
\hline Fiscal freedom & 3.69 & Reject $H_{0}$ & The type of group has an impact on fiscal freedom \\
\hline
\end{tabular}




\begin{tabular}{|c|c|c|c|}
\hline $\begin{array}{l}\text { Government } \\
\text { spending }\end{array}$ & 1.58 & Accept $H_{0}$ & $\begin{array}{l}\text { The type of group has no impact on government } \\
\text { spending }\end{array}$ \\
\hline $\begin{array}{l}\text { Freedom } \\
\text { investment }\end{array}$ & 1.93 & Accept $H_{0}$ & $\begin{array}{l}\text { The type of group has no impact on freedom for } \\
\text { investment }\end{array}$ \\
\hline Monetary freedom & 5.26 & Reject $H_{0}$ & $\begin{array}{l}\text { The type of group has an impact on monetary } \\
\text { freedom }\end{array}$ \\
\hline $\begin{array}{l}\text { Human development } \\
\text { index (HDI) }\end{array}$ & 6.01 & Reject $H_{0}$ & The type of group has an impact on HDI \\
\hline Freedom of property & 7.10 & Reject $H_{0}$ & $\begin{array}{l}\text { The type of group has an impact on freedom of } \\
\text { property }\end{array}$ \\
\hline Freedom of work & 2.45 & Accept $H_{0}$ & $\begin{array}{l}\text { The type of group has no impact on the freedom of } \\
\text { work }\end{array}$ \\
\hline
\end{tabular}

Inspection of Table (3) reports more clearly that the GCC countries are distinguished from other Arab countries in six governance variables and HDI indicator. Based on the MANOVA analysis, we can say that, in the Arab countries of the Gulf (GCC), we identify a weaker corruption, freedom of trade with less legislative or regulatory limits, a greater economic freedom, a fiscal freedom close to 100 (this means that the tax burden is lower and consequently individuals and companies have little tax liability), a monetary freedom better controlled according to the objectives, a significantly higher human Development Index (HDI), and finally a freedom of property with less expropriations and a lower level of corruption for the sale or purchase of goods. The high values of the HDI indicator in the GCC countries are partly explained by the indicator of gross domestic product per capita (IPIB) which is very high in the six Arab Gulf countries. Indeed, the GCC region includes $40 \%$ of oil reserves and $23 \%$ of natural gas reserves. These reserves are making the GCC members major producers and exporters of oil. In addition, the GCC countries have large reserves of foreign currency due to the increase in global oil demand and as well as its price from 2001 to the first half of 2008. As a result, the GCC countries have a significant impact on the international financial markets. At the end of 2008, they were classified second after China as net capital exporters. Indeed, $13.6 \%$ of exports of capital in the world come from Kuwait, Saudi Arabia, and the UAE, 23.4\% from China and 12.9\% from Germany (IMF Global Financial Stability Report, October 2009). In addition, three of the main sovereign authorities currently operating in international markets are in this region, namely, the Qatar Investment Authority (QIA), the Abu Dhabi Investment Authority (ADIA) and the Kuwait Investment Authority (KIA). The Institute of International Finance (IIF) estimated that approximately 630 billion American dollars are circulated by those countries, that amount will become 1.1 trillion if reserves run by the Saudi Arabia Monetary Agency are included (SAMA) (IIF, $2009)^{7}$.

The above considerations explain why the GCC region has maintained an average annual growth rate of $6.4 \%$ even in 2008 , while zero or negative rates have characterized the world

${ }^{7}$ Institute of International Finance (IIF) (2009). Large Net External Asset Provide a Key Buffer During the Global Crisis, GCC Regional Overview, September 28. 
after the last global financial crisis (IMF, 2010) ${ }^{8}$, such a crisis began to spread globally from the second half of 2007.

\section{Conclusion}

The MANOVA analysis used in this paper, applied to each of 11 variables of governance and the HDI indicator in temporal data, and 17 Arab countries, allowed to discriminate on the one hand between the Arab countries divided into republican regimes and monarchical regimes, and on the other hand between those in the GCC countries and the group of other countries. Discrimination happened between the two types of regimes and it is clear for the variables: freedom of corruption, freedom of trade, freedom of economy, and freedom of property. In republican regimes, low values associated with the degree of freedom of corruption, mean that corruption is relatively high compared to monarchies, and it severely restricts freedom of individuals, as well as freedom of trade and freedom of economy. Finally, for the degree of freedom of property, there are more expropriations and a higher level of corruption in the sale or purchase of goods. While the discrimination between the GCC countries and other countries is manifested in six variables: freedom of corruption, freedom of trade, freedom of economy, freedom of fiscal, freedom of money, freedom of property, and finally the human development index (HDI) which is associated with the measurement of happiness and standard of life. In the GCC countries, we identify weaker corruption, freedom of trade with less regulatory limits, greater economic freedom, fiscal freedom meaning that the tax burden is lower and consequently individuals and companies have little tax liability, monetary freedom better controlled according to the objectives, a significantly higher human Development Index (HDI), and finally freedom of property with less expropriations and a lower level of corruption for the sale or purchase of goods.

We address politicians in the Arab world who hold power and making decisions related to the fate of their countries by urging them to consider investing in individual citizens and to make this step a fundamental objective present at any time in their thinking and in their daily actions. With that thought in mind, we ask the following questions: What are the barriers that have prevented arable countries to align with developed countries? Where are we from modern civilization? The transition from ignorance to knowledge, from ruin to construction, from disorder to order, from fraud to integrity, and from unemployment to work cannot be achieved without the constructive force exerted by each individual and each leader; an effort to change without any ambiguity. Arab countries are now called to reconsider their underdeveloped concepts of nation, country, responsibility, religion and democracy. We urgently need to live in civil harmony and in a climate of political stability by establishing the political model that reflects our dreams and those of future generations: it is the "Rule of law" and the "Primacy of the law".

\section{References}

Ahishakiye, H. (2009). Gouvernance économique et croissance au Burundi: approche en

${ }^{8}$ IMF (2010), World Economic Outlook, April. IMF (2010), Regional Economic Outlook: Middle East and Central Asia, May. 
terme de causalité. Revue de l'Institut de Développement Economique (RIDEC), 3(3),37-70.

Andrei, T., Matel, A., \& Rosca, I. G. (2009). The Corruption: An Economic and Social Analysis. Collection of Socio-economics, Economica.

Andrei, T., Stancu, S., Nedelcu, M., \&Matei, A. (2007). Econometric Models used for the Corruption Analysis. MPRA Paper No. 19623, posted 30. December 2009 10:03 UTC. https://mpra.ub.uni-muenchen.de/19623/1/ .

Apaza, C. R. (2009). Measuring Governance and Corruption through the Worldwide Governance Indicators: Critiques, Responses, and Ongoing Scholarly Discussion. Political Science \& Politics, 42(1), 139-143. https://doi.org/10.1017/S1049096509090106

Arab Anti-Corruption Organization (2012).

http://arabanticorruption.org/articleCat/56/AACO-Publications.

Ben Néfissa, S. (2000). Organisation Non Gouvernementale (ONG), Gouvernance et développement dans le monde arabe.Table ronde intitulée "ONG et Gouvernance dans le monde arabe", organisé dans le cadre du Programme MOST de l'UNESCO, au Caire en mars 2000, document de Travail - no 46. http://unesdoc.unesco.org/images/0012/001204/120462Fo.pdf

Bonny, J. B. A. (2005). Mauvaise gouvernance et faibles investissements directs étrangers en Haïti. Conférence Générale «Insécurité et Développement » de l'Association Européenne des Instituts de Recherche et de Formation en matière de Développement (EADI), Bonn, 21-24 septembre 2005. https://globaljournals.org/GJMBR_Volume13/2-Governance-and-FDI-Attractiveness.pdf

Bou-Hamad, I., Mourad, M., \& Duchesne, P. (2013). Trade between the U.S. and the GCC Countries: Evidence from Causality and Cointegration Analysis. International Research Journal of Finance and Economics, 122, 162-171.

Castel, O. (2006). Bonne gouvernance versus démocratie : les rhétoriques de la Banque mondiale et des ONG du Nord face aux réalités. La démocratie au péril de l'économie, 327-49.

https://halshs.archives-ouvertes.fr/file/index/docid/119522/filename/FrB-Castel2_texte_pour_ $\mathrm{pu}$

Djaowe, J. (2009). Investissements Directs Etrangers (IDE) et gouvernance : les pays de la CEMAC sont-ils attractifs ? Revue Africaine de l'Intégration, 3(1), 1-32.

Fatafta, M. (2018). Rampant Corruption in Arab States. Transparency International. https://www.transparency.org/news/feature/.

Gambetta, D. (2000). Corruption: An Analytical Map. In S. Kotkin and A. Sajo (eds.), Political Corruption of Transition: A Skeptic's Handbook, Central European University Press.

Ghoneim, \& Ezzat. (2016). Growth and corruption in Arab countries: What type of 
relationship connects them? Journal of Economics and International Finance, 8(5), 44-55.

Halleröd, B., Rothstein, B., Daoud, A., \& Nandy, S. (2013). Bad Governance and Poor Children: A Comparative Analysis of Government Efficiency and Severe Child Deprivation in 68 Low- and Middle-income Countries. World Development, 48, 19-31. https://doi.org/10.1016/j.worlddev.2013.03.007

Harb, K. I. (2017). The Quandary of Bad Governance in the Arab World. Arab Center Washington DC. http://arab center dc.org/policy-analyses.

Hattar, K. (2017). Middle East nd North Africa: A Very Drastic Decline. Transparency International. https://www.transparency.org/news/feature/.

IMF (2009). Global Financial Stability Report, October 2009: Navigating the Financial Challenges Ahead. ttps://www.imf.org/en/Publications/GFSR/Issues/2016/12/31/.

IMF (2010), Regional Economic Outlook: Middle East and Central Asia, May

IMF (2010), World Economic Outlook, April.

Institute of International Finance (IIF) (2009). Large Net External Asset Provide a Key Buffer During the Global Crisis, GCC Regional Overview, September 28.

Mauro, P. (1995). Corruption and growth. The Quarterly Journal of Economics, 110(3), 681-712. https://doi.org/10.2307/2946696

Merza, E., \& Cader, H. (2009). Determining the Exchange Rate of the Common GCC Currency under a Fixed Exchange Rate Regime. International Review of Business Research Papers, 5(4),192-199.

Miossec, J. M. (2008). Le développement local entre mondialisation et promotion des territoires. Partie 2 du livre «Développement local, gouvernance territoriale : Enjeux et perspectives », Éditions Karthala.

Mourad, M., \& Henniche, W. (2014). Management governance in the Arab world: MANOVA Analysis. The 13Th International Annual Conference (Crisis Management in a Changing World), 21-23 April 2014, Amman, Jordan.

Nazer, Y. (2016). Causes of inflation in Saudi Arabia. The Business and Management Review, 7(3), 147-154.

Ndinga, M. M. A. (2002). La gouvernance économique: quelles incidences sur le développement au Congo-Bazzaville ? Afrique et développement, 27(1/2), 1-24.

Organisation for Economic Co-Operation and Development (OECD) (2005). Annual Report. https://www.oecd.org/about/34711139.pdf

Seber, G. A. F. (2004). Multivariate observations. Wiley series in probability and statistics.

Transparency International TI (2018). Rampant corruption in Arab states. https://www.middleeastmonitor.com/20180222-rampant-corruption-in-arab-states-transparenc y-international-says/. 
Transparency International's Global Corruption Barometer (2013).

https://www.transparency.org/gcb2013/report

UNDP (2012). The Sustainable Future We Want.

http://www.undp.org/content/undp/en/home/librarypage/corporate.

United Nations Conference on Trade and Development (UNCTAD) (2006). http://unctad.org/en/docs/tdr2006_en.pdf

United Nations Development Programme (UNDP) (1997). Governance for sustainable human development, UNDP policy document, New York.

http://www.sciepub.com/reference/188032.

Wigg, A., Tondel, L., \& Villanger, E. (2007). Will International Trade Reduce Poverty? A Background Note to NORAD. Bergen: CHR. Michelsen Institute (CMI Report R 2007: 16).

World Bank (1992). Governance and development. The World Bank Washington, D.C. http://documents.worldbank.org/curated/en/604951468739447676/.

https://doi.org/10.1596/0-8213-2094-7

World Bank. (2003). Better Governance for Development in the Middle East and North Africa: Enhancing Inclusiveness and Accountability. Report Number 27146. https://openknowledge.worldbank.org/handle/10986/15077

Yenikoye, I. A. (2004). La gouvernance sous la verépublique au niger 2000-2004. L'Harmattan, Niger.

Zimeray, F. (2010). La gouvernance démocratique et les droits de l'homme. Ministère des Affaires Étrangères et Européennes, Direction générale de la mondialisation, du développement et des partenariats.

https://www.diplomatie.gouv.fr/IMG/pdf/DH_Gouvernance_democrat_241110.pdf

\section{Copyright Disclaimer}

Copyright for this article is retained by the author(s), with first publication rights granted to the journal.

This is an open-access article distributed under the terms and conditions of the Creative Commons Attribution license (http://creativecommons.org/licenses/by/4.0/). 